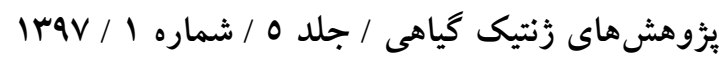

تعيين الكوى تنوع زنتيكى تودهاى بومى كندم ايران بر مبناى نشانكر مولكولى ISSR و صفات

مورفولوزيكى

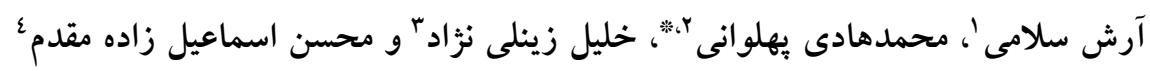

ا- دانش آموخته كارشناسى ارشد، كروه اصلاح نباتات و بيو تكنولوزى، دانشكاه علوم كشاورزى و منابع طبيعى گر كان، كر كان

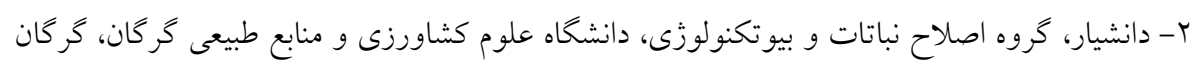

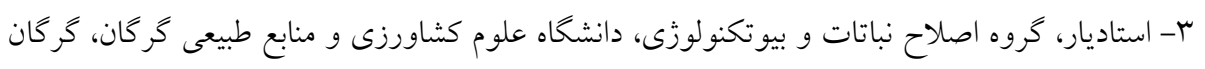

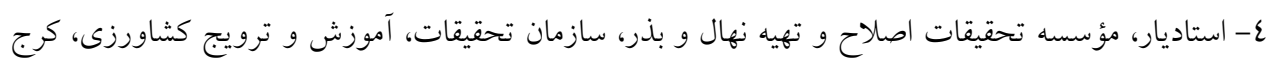

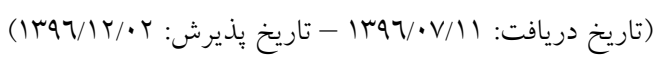

جمع آورى و نخهدارى زرميلاسم، بخصوص تودههاى بومى كونههاى مهم زراعى و سازماندهى اطلاعات مربوط به آنها، علاوه

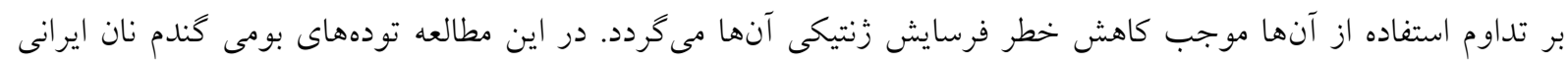

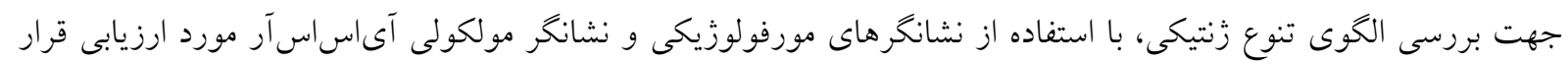

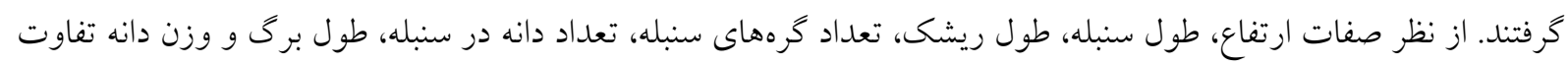

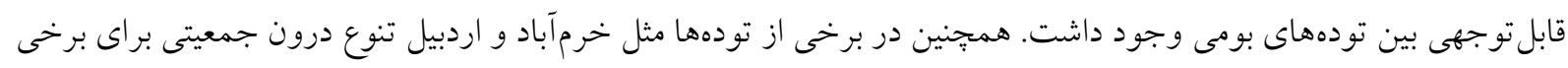

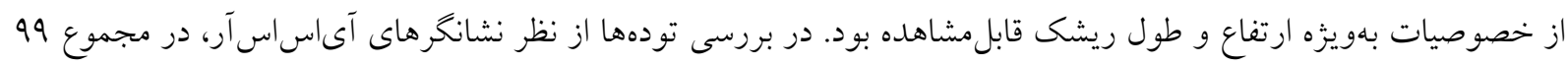

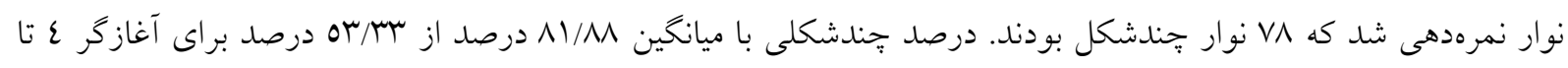

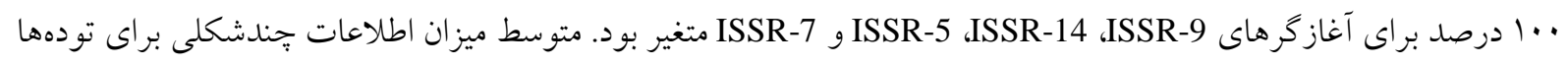

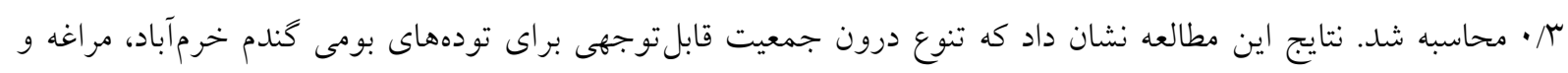

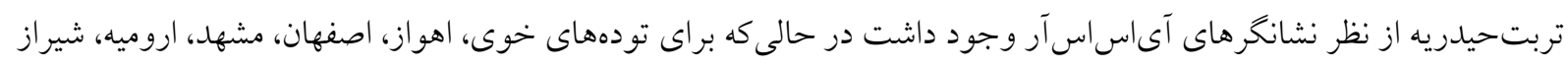

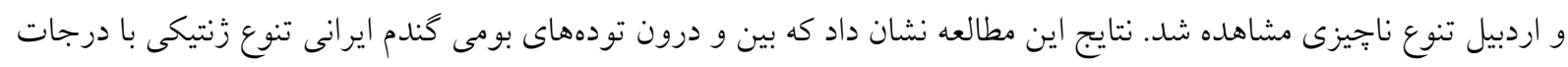

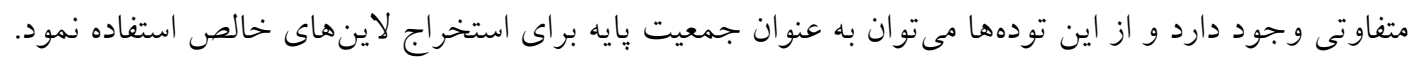
وازگَان كليدى: آىاساسآر، تنوع زنتيكى، زرميلاسم، كروهبندى 
قابلدسترس در برنامهاى اصلاحى مىباشند، ولى هنوز

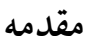
تعداد زيادى از اينگ كونها در ايران ناشناخته مىباشند. محدوده جغرافيايى بهشدت با تعيين سطح تنوع زنتيكى در سطح كونهاى متنوع در ارتباط است (Zhou et al., 2008). Gulnar سطح تنوع زنتيكى تودههاى بومى گُندم دوروم، الح رقم از

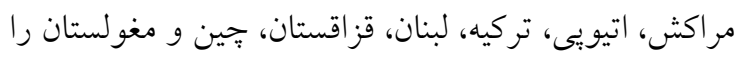

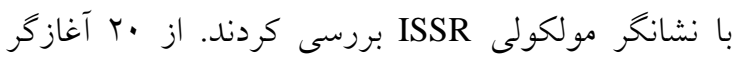

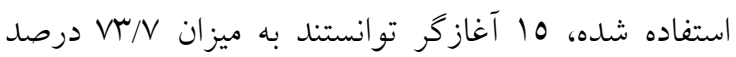

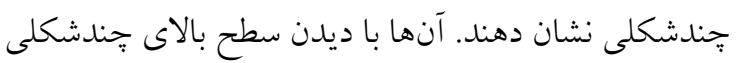
در اين مجموعه از كُندمهاى دورم احتمال دادند كه هلال

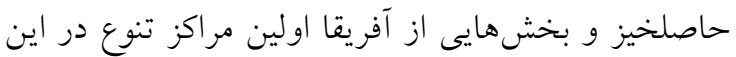

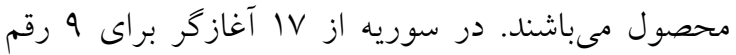

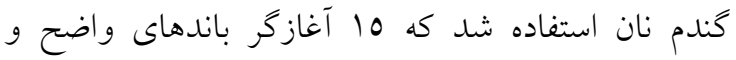
متنوعى با 1/9N/ درصد تكراريذيرى نشان دادند كه بر بان اساس اين مطالعه، استفاده از روش ISSR مىتواند يك ابزار قدرتمند براى شناسايى تنوع زنتيكى بين ارقام گندم نان

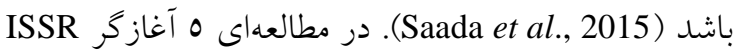

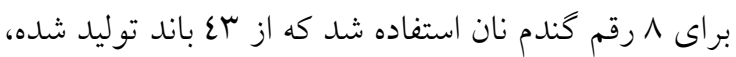

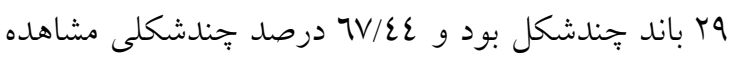

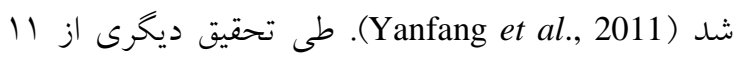

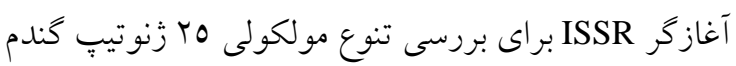

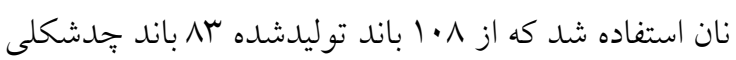

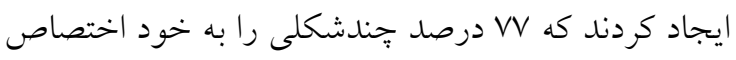

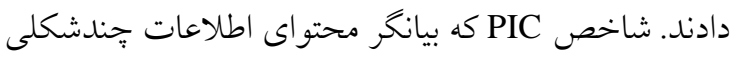

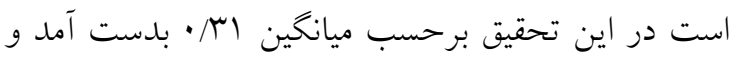

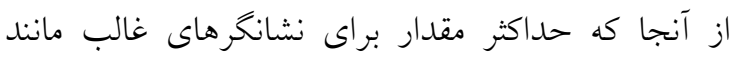

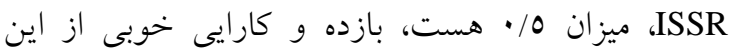
نشانگر را نشان داد (Zamanianfard et al., 2015). در بر بران تجزيه و تحليل تنوع زنتيكى و روابط بين زنوتيٍهاى گندم

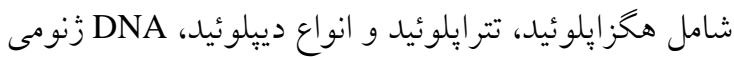
از •r رقم كندم با نشانكر ISSR بررسى شد كه از 1 آغازكر

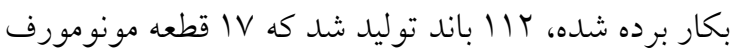

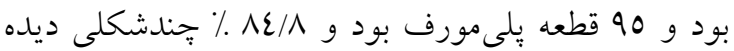


نامهاى شيراز، خرمآباد، خوى، اهواز، اصفهان، مراغه،

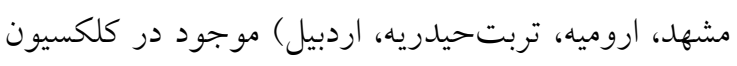
بخش تحقيقات غلات و موسسه تحقيقات اصلاح و تهيه

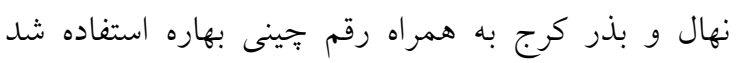

جدول ا - تودهاى بومى كندم ايرانى مورد استفاده در اين مطالعه

Table 1. Iranian wheat landraces used in the

\begin{tabular}{ccc}
\hline & شماره توده بومى $\begin{array}{c}\text { شماره } \\
\text { Lace of collection }\end{array}$ & $\begin{array}{c}\text { Landrace } \\
\text { no. }\end{array}$ \\
& $\begin{array}{c}\text { nollection } \\
\text { no. }\end{array}$ & \\
\hline Khoramabad & 676 & 1 \\
Khoy & 1579 & 2 \\
Ahwaz & 1643 & 3 \\
Isfahan & 1720 & 4 \\
Maragheh & 1854 & 5 \\
Mashhad & 1963 & 6 \\
Urmia & 2512 & 7 \\
Torbat-e & 1131 & 8 \\
Shiraz & 2597 & 9 \\
Ardabil & 2616 & 10 \\
\hline
\end{tabular}

بذور در هاييز rar| بهصورت ^ خطط به طول / / متر براى

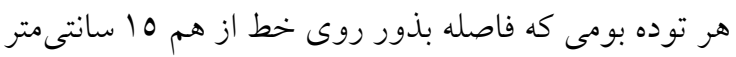
بود، در دو بلوك در مزرعه كشت شد. در اين مطالعه V صفت ارتفاع بوته، طول ريشك، طول سنبله، طول برى

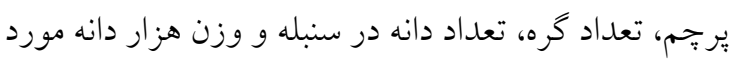

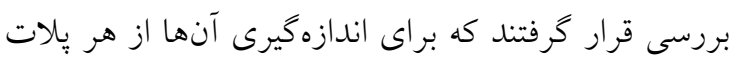

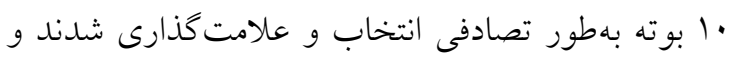
صفات مورفولوزيكى بر روى اين بوتهها در مزرعه و

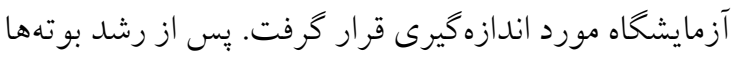

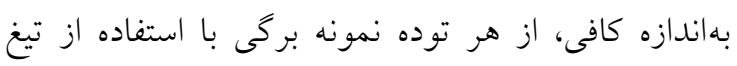

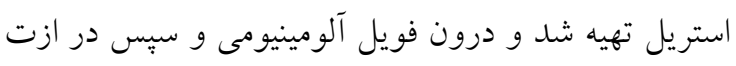
مايع قرار كرفت. بس از آن نمونهها به فريزر • •م- درجه

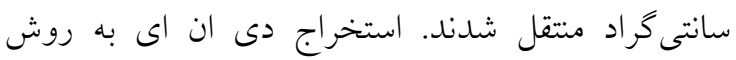
(Doyle and Doyle, 1987) Doyle and Doyle كَرفت و از دو روش اسيكتروفتومتر و زل آكَارز براى تعيين كميت و كيفيت دىاناى استخراج شده استفاده شد. براى

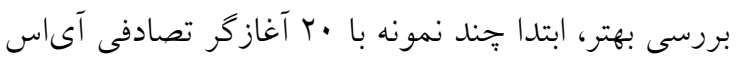

شد (Abou-Deif et al., 2013). Carvalho و همكاران (Carvalho et al., 2010) ^ع رقم گُندم نان را مورد تجزيه تحليل قراردادند. آنها از

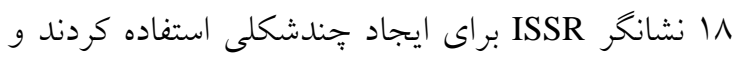

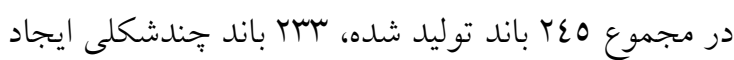

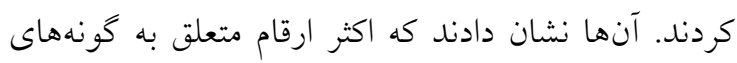

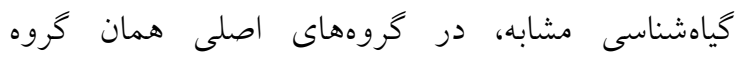

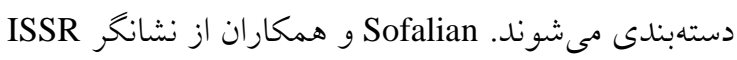

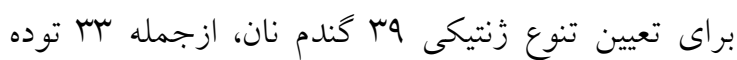

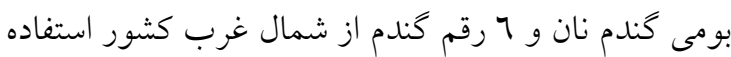

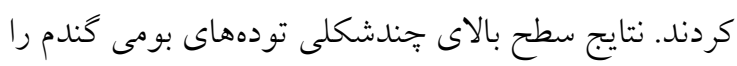
بر اساس اين نشانكر نشان داد همجِنين نشان داده شد كه بهان

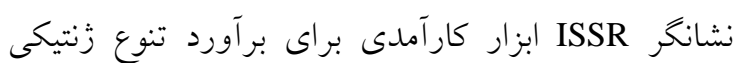

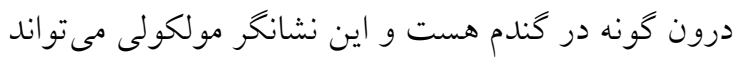
تودههاى بومى بدست آمده از مكانهاى مختلف را متمايز كند (Sofalian et al., 2008). در تحقيق ديخرى، به طور

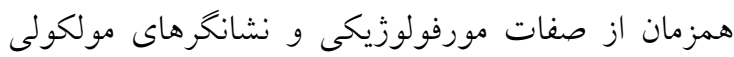
براى بررسى تنوع زنتيكى ارقام گُندم با هدف تعيين

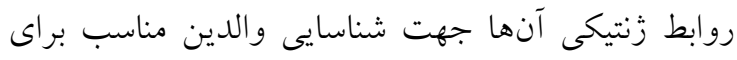
برنامه هاى اصلاحى و زنتيكى استفاده شد ( Nazari and

.(Abdolshahi, 2014

بررسى مطالعات انجام شده نشان مىدهد كه اخرجه

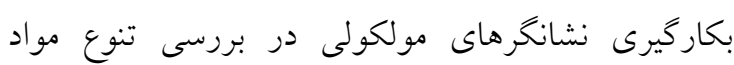

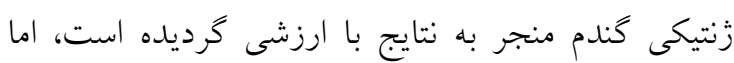

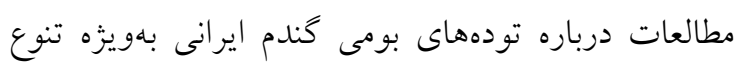

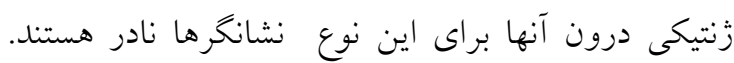

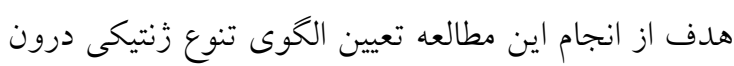

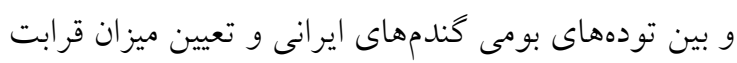

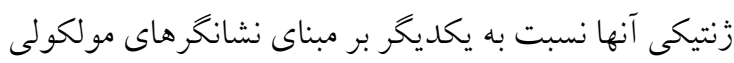

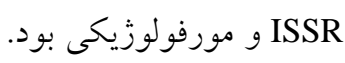

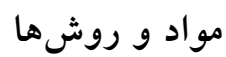
اين آزمايش در مزرعه نمونه شماره ا 1 دانشخاه علوم

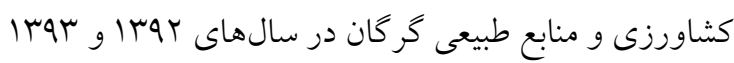

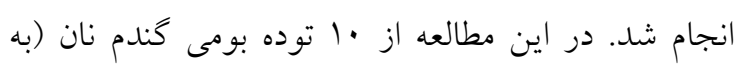


ميانخين ارتفاع رقم شاهد (جينى بهاره) با 97 سانتى متر،

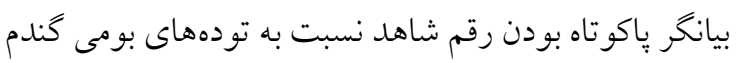
نان است. از نظر طول سنبله تودهاى اصفهان با 11 سانتىمتر و اردبيل با V/A سانتىمتر به ترتيب بيشترين و كمترين بودند. صفات تعداد گرههاى سنبله، تعداد دانه در

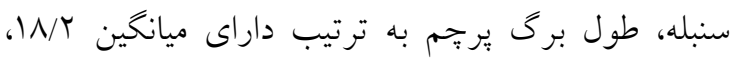


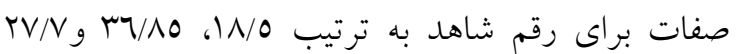
سانتىمتر كمتر بود. وزن هزار دانه در نمونههاى گندم نان

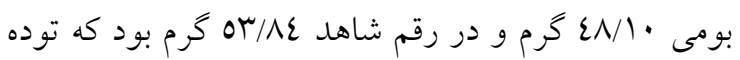
اردبيل با وزن هزار دانه ب./rع گرم كمترين و توده اصفهان

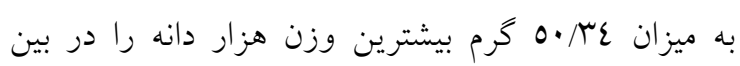
تودهها داشتند (جدول r). وجود دامنه وسيع تنوع براى خصوصيات مورفولوزيك در تودهاى مختلف بيانكر آن است كه از افراد اين تودهها مىتوان براى ايجاد جوامع بايه

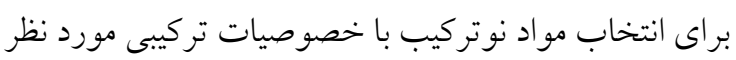

$$
\text { در برنامههاى اصلاحى سود جست. }
$$

طبق نتايج حاصل از آمار توصيفى، براى تودههاى بومى جنى

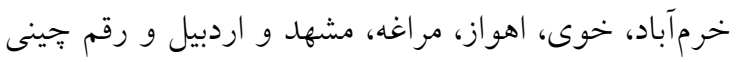
بهاره بيشترين ضريب تغييرات در ارتفاع بوته و كمترين آن

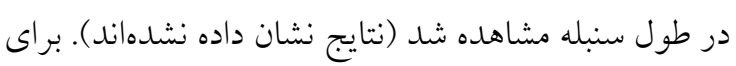
توده اصفهان، طول برى يرجم از بيشترين و تعداد دانه در سنبله از كمترين ضريب تغييرات برخوردار بودند. بنابر اين صفت طول برى يرجم بيشترين و تعداد دانه در سنبله كمترين تنوع را در مزرعه داشتند. براى توده تربت حيدريه،

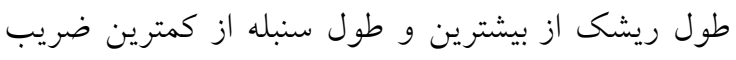

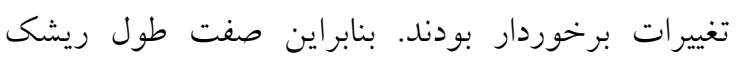
بيشترين و طول سنبله كمترين تنوع را در مزرعه داشتند. براى توده شيراز، طول برگ يرجّم از بيشترين و طول سنبله از كمترين ضريب تغييرات برخوردار بودند. بنابراين صفت بر بردي

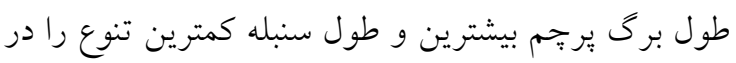
مزرعه داشتند. - مزا.
اسآر مورد ارزيابى اوليه قرار كرفت. سبِ ••آخازكر كه

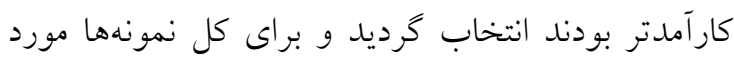

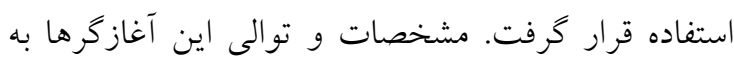
همراه دماى اتصال آنها، در جدول r آورده شده است. واكنش زنجيره بلى مراز با استفاده از دستخاه ترموسايكلر در حجم نهايى 10 ميكروليتر انجام يذيرفت. بهمنظور

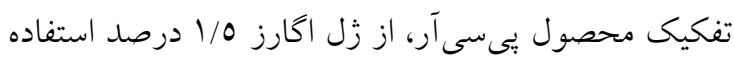

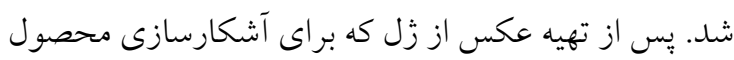

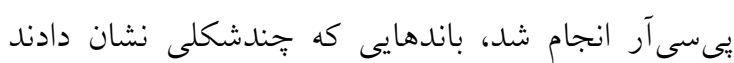
بلهورت يك و صفر (براى حضور و عدم حضور) امتيازبندى شدند. براى محاسبه و تشكيل ماتريس تشابه از وركرئ رويه SimQual و ايجاد اين ماتريس به سه روش تطابق ساده، دايس و جاكارد، و براى گروهبندى از رويه SAHN به روش UPGMA نرم|فزار انتىسيس سرى ؟ •/ استفاده

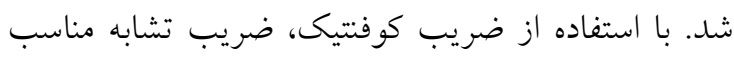
انتخاب كرديد. جهت تعيين كارآيى الكوريتم مورداستفاده

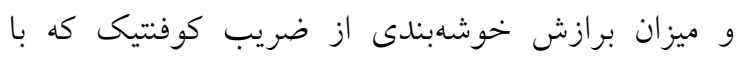

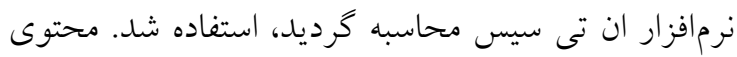

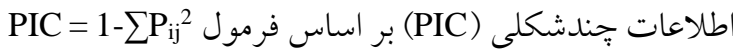

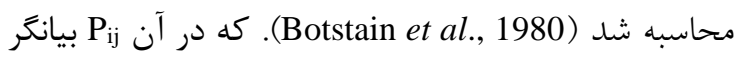
فراوانى آلل زام براى نشانگر iام است. ميزان اطلاعات جندشكلى براى نشانگرهاى غالب حداكثر 10 • است. براى محاسبه آمار توصيفى دادههاى مورفولوزيكى از نرمافزار سرى S/r استفاده شد. SAS

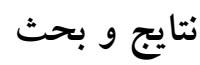
ميانكين صفات اندازهيرى شده در تودهاى مورد بررسى

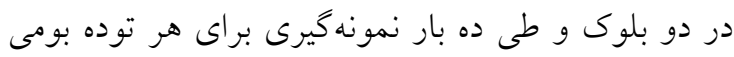

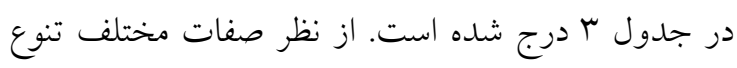
زيادى بين تودهها وجود داشت. ميانخين صفات براى هر توده اندازهكيرى شد. نتايج نشان داد كه از نظر ارتفاع تنوع نيان بين N N مانتىمتر (توده بومى اردبيل) و 1Y/90 سانتىمتر (توده بومى خوى) متفاوت بود كه در برابر 
جدول ץ- نام، توالى و دماى اتصال آغازگرهاى آىاساس آر مورد استفاده در مطالعه تودههاى بومى گندم ايران

Table 2. Name, sequence and annealing temperature of ISSR primers used to study Iranian wheat landraces

\begin{tabular}{|c|c|c|}
\hline 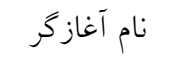 & 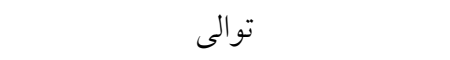 & دماى اتصال (درجه سانتى گراد) \\
\hline Primer name & Sequence (5'-3') & Annealing temperature $\left({ }^{0} \mathrm{C}\right)$ \\
\hline ISSR-9 & CACACACACACACAGCG & 52 \\
\hline ISSR-2 & CACACACACACACAGCC & 52 \\
\hline ISSR-10 & CACACACACACACACAATC & 52 \\
\hline ISSR-7 & TGTGTGTGTGTGTGTGATC & 52 \\
\hline ISSR-5 & GTGTGTGTGTGTGTGTGC & 56 \\
\hline ISSR-14 & AGAAGAGAGAGAGAGACT & 52 \\
\hline ISSR-4 & AGAGAGAGAGAGAGAGGCC & 56 \\
\hline ISSR-1 & GAGAGAGAGAGAGAATG & 50 \\
\hline ISSR-3 & AGAGAGAGAGAGAGAGT & 52 \\
\hline ISSR-20 & ССАСТСТСТСТСТСТСТСТ & 56 \\
\hline
\end{tabular}

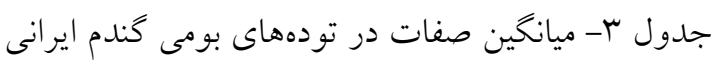

Table 3. Mean of traits for Iranian wheat landraces

\begin{tabular}{|c|c|c|c|c|c|c|c|}
\hline توده بومى & $\begin{array}{l}\text { ارتفاع } \\
\text { Height } \\
\text { Cm }\end{array}$ & $\begin{array}{c}\text { طول سنبله } \\
\text { Spike } \\
\text { length } \\
\text { Cm }\end{array}$ & $\begin{array}{c}\text { رول } \\
\text { Own } \\
\text { length }\end{array}$ & $\begin{array}{c}\text { تعداد گرههاى سنبله } \\
\text { No. spike node }\end{array}$ & $\begin{array}{c}\text { تعداد دانه در } \\
\text { No. seed per } \\
\text { spike }\end{array}$ & 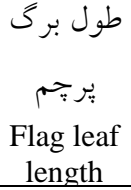 & $\begin{array}{c}\text { وزن هزار دانه } \\
1000 \text { seed } \\
\text { weight }\end{array}$ \\
\hline Khoramabad & 116.72 & 8.40 & 5.80 & 16.0 & 31.50 & 26.50 & 45.90 \\
\hline Khoy & 142.95 & 8.20 & 5.25 & 14.5 & 28.50 & 27.35 & 42.20 \\
\hline Ahwaz & 127.19 & 8.55 & 5.40 & 16.5 & 32.45 & 25.95 & 47.10 \\
\hline Isfahan & 107.13 & 11.0 & 6.85 & 22.5 & 42.05 & 22.75 & 50.34 \\
\hline Maragheh & 120.81 & 9.05 & 6.25 & 19.0 & 37.35 & 24.55 & 49.16 \\
\hline Mashhad & 118.41 & 9.20 & 4.80 & 20.0 & 39.35 & 28.20 & 52.87 \\
\hline Urmia & 89.57 & 9.45 & 6.05 & 21.5 & 42.45 & 29.05 & 52.45 \\
\hline Torbat-e & 83.01 & 8.70 & 5.55 & 19.0 & 37.35 & 24.85 & 43.45 \\
\hline Shiraz & 126.73 & 9.50 & 6.35 & 18.5 & 36.55 & 24.25 & 44.12 \\
\hline Ardabil & 83.87 & 7.80 & 6.05 & 14.5 & 28.60 & 28.55 & 43.03 \\
\hline Chinese spring & 96.00 & 8.90 & 0.00 & 18.5 & 36.85 & 27.70 & 49.25 \\
\hline
\end{tabular}

با استفاده از اجزاى متشكله واريانس صورت گرفت (جدول ع). در مورد ارتفاع بوته و طول برك برجّم ميزان تنوع درون تودهاى بيش از ميزان تنوع بين تودهها بود درحاليكه براى صفات تعداد دانه در سنبله، طول سنبله و تعداد كرههاى سنبله تنوع مشاهله شده بين تودهها بيش از

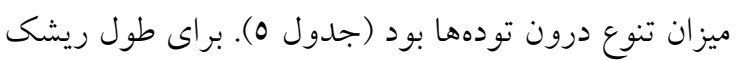
ميزان تنوع درون و بين تودهها تقريبا يكسان بود (جدول 0). اين يافته نشان مىدهد كه روند اصلاح كندم توسط كشاورزان به همراه انتخاب طبيعى بيشتر بر اجزاى عملكرد دانه در كُندم و صفات مرتبط شامل تعداد دانه در سنبله، طول سنبله و تعداد گره متمركز بوده و براى صفات مربوط
بررسى نتايج نشان داد كه ضريب تغييرات صفات در تودههاى بومى مورد استفاده نسبت به رقم شاهد، بيانگر تنوع بهمراتب بيشتر همه صفات مورد بررسى در تودههاى

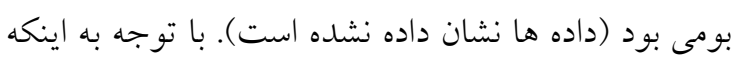

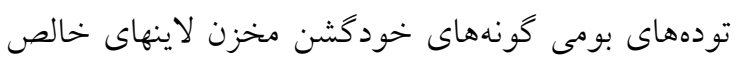
محسوب مىشوند، تنوع مشاهده شده درون اين تودهها ماده خام بارزشى براى يافتن لاينهاى حاوى زنهاى مفيد براى بهبود خصوصيات مورفولوزيك كندم نان است كه مىتوان از آن در بروزمهاى اصلاحى بهره گرفت.

بررسى بزركى ميزان تنوع درون و بين تودههاى گندم از طريق محاسبه ضريب تغييرات (CV) درون و بين جمعيت 
در اين مطالعه ابتدا ب نمونه از هر توده بومى بر اساس تنوع مورفولوزيكى موجود در مزرعه انتخاب و مورد بررسى قرار

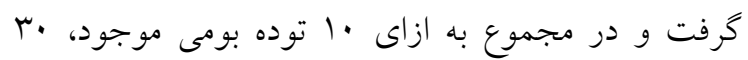

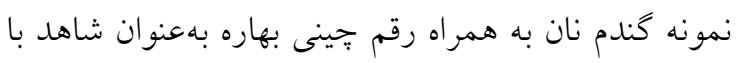

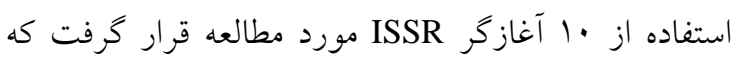
نتايج آن شامل نام آغازگر، تعداد باندهاى توليدشده، تعداد باندهاى جندشكل، درصد باندهاى جند شكل و محتواى اطلاعات جندشكل در جدول 7 آمده است. تمامى ده جفت آغازكر ISSR بهكار رفته در اين آزمايش جندشكلى نشان دادند و در مجموع 99 نوار نمرهدهى شد كه VN نوار خند شكل بودند. تعداد نوارهاى جند شكل از متا 77 نوار براى هر آغازگر متغير بود. بيشترين نوار جند شكل مربوط به

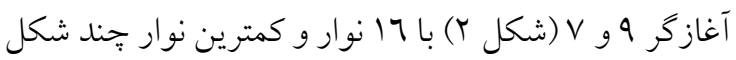
مربوط به آغازگر عا با مبوار بود و تعداد متوسط باندهاى توليد شده 9/9 و متوسط تعداد باندهاى جند شكل حاصل V/A بود (جدول 7). درصد جندشكلى از سر/ه درصد براى آغازگر ع با كمترين درصد جندشكلى تا . ․ براى آغازگرهاى 9، عا، 0 و V متغير بود. ميانخين درصد جندشكلى 1N/N1 درصد محاسبه شد. ميزان اطلاعات جندشكلى (PIC) براى هر آغازگر بهطور جداكانه براى كل تودمها محاسبه
به رشد رويشى نظير ارتفاع بوته و طول برى مخزن زنى تودههاى بومى گندم به تثبيت نرسيدهاند. اين موضوع

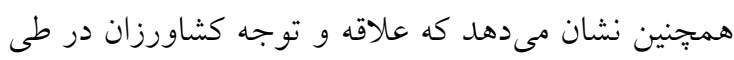
سالهاى انتخاب به موضوع عملكرد دانه بيش از توليد

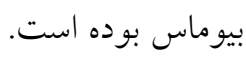
دستهبندى نمونهها نيز با استفاده از تجزيه خوشهاى (تجزيه كلاستر) به روش UPGMA و با استفاده از مربع فاصله اقليدسى بهعنوان معيار تشابه بر روى دادههاى مورفولوزيكى انجام شد (شكل (1). تجزيه كلاستر، تودههاى مورد بررسى را به سه گروه تفكيك نمود كه گروه اول شامل تودههاى خرمآباد، مراغه، مشهل، اهواز، شيراز و اصفهان، كروه دوم شامل توده خوى و گروه سوم شامل تودههاى اروميه، تربتحيدريه، اردبيل و جينى بهاره (رقم شاهد) بودند. يكى از كاربردهاى مهم نتايج تجزيه خوشهاى يافتن والدين تلاقى در برنامهاى تلاقى و توليد ارقام هيبريد است. تودههاى موجود در گروه اول و سوم داراى بيشترين فاصله زنتيكى با هم بوده و لذا در برنامه هاى بهنز ادى جهت ايجاد ارقام هيبريد، تلاقى بين افراد و يا لاينهايى از آنها منجر به توليد نتاج بهترى خواهد شد. Nikooseresht و Najafian Nikooseresht and ) تجزيه خوشهاى استفاده نمودهاند

(Najafian, 2016

جدول ع- تجزيه واريانس بين و درون تودههاى بومى گندم نان ايرانى

Table 4. Analysis of variance inter and intra Iranian wheat landraces

\begin{tabular}{|c|c|c|c|c|c|c|c|}
\hline \multirow[b]{2}{*}{$\begin{array}{l}\text { منبع تغييرات } \\
\text { S.O.V }\end{array}$} & \multirow[b]{2}{*}{$\begin{array}{c}\text { آزادى درجه } \\
\text { d.f }\end{array}$} & \multicolumn{6}{|c|}{ ميانخين مربعات (MS) } \\
\hline & & $\begin{array}{l}\text { طول برگ } \\
\text { Flag leaf } \\
\text { length }\end{array}$ & $\begin{array}{l}\text { ارتفاع } \\
\text { Height }\end{array}$ & $\begin{array}{l}\text { تعداد دانه } \\
\text { در سنبله } \\
\text { No. seed } \\
\text { per spike }\end{array}$ & $\begin{array}{l}\text { سول } \\
\text { Spike } \\
\text { length }\end{array}$ & $\begin{array}{c}\text { تعداد گرههاى } \\
\text { سنبله } \\
\text { No. spike } \\
\text { node }\end{array}$ & $\begin{array}{c}\text { رول } \\
\text { Own } \\
\text { length }\end{array}$ \\
\hline $\begin{array}{c}\text { Inter population } \\
\text { بين توده }\end{array}$ & 9 & $42.98 * *$ & $63.84 * *$ & $331.22 * *$ & $9.45 * *$ & $89.65 * *$ & $3.99 * *$ \\
\hline 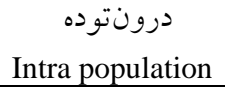 & 90 & 5.54 & 6.96 & 11.13 & 0.12 & 2.9 & 0.42 \\
\hline كل Total & 99 & & & & & & \\
\hline
\end{tabular}




$$
\text { جدول 0- ضريب تغييرات (\%) بين و درون تودههاى بومى گندم ايرانى }
$$

Table 5. Coefficient of variation (\%) inter and intra Iranian wheat landraces

\begin{tabular}{|c|c|c|c|c|c|c|}
\hline $\begin{array}{c}\text { ضريب تغييرات (\%) } \\
\text { Coefficient of variation (\%) }\end{array}$ & $\begin{array}{c}\text { طول برگ يرجم } \\
\text { Flag leaf } \\
\text { length }\end{array}$ & $\begin{array}{c}\text { ارتفاع } \\
\text { Height }\end{array}$ & $\begin{array}{c}\text { تعداد دانه } 2 \text { مر سنبله } \\
\text { No. seed } \\
\text { per spike }\end{array}$ & $\begin{array}{c}\text { سول } \\
\text { سنبله } \\
\text { Spike } \\
\text { length }\end{array}$ & $\begin{array}{c}\text { تعداد گرههاى } \\
\text { سنبله } \\
\text { No. spike } \\
\text { node }\end{array}$ & $\begin{array}{r}\text { ريشك } \\
\text { Own } \\
\text { length }\end{array}$ \\
\hline $\begin{array}{c}\text { Inter population } \\
\text { بين توده }\end{array}$ & 7.21 & 3.74 & 15.31 & 10.62 & 16.01 & 10.11 \\
\hline $\begin{array}{c}\text { درون توده } \\
\text { Intra population }\end{array}$ & 8.78 & 4.13 & 9.08 & 3.81 & 9.26 & 10.92 \\
\hline
\end{tabular}

$$
\text { جدول 7- آغاز خرهاى آىاساسآر استفاده شده و نتايج تكثير آنها }
$$

\begin{tabular}{|c|c|c|c|c|}
\hline 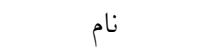 & تعداد باندهاى & تعداد باندهاى & درصد باندهاى & محتواى اطلاعات \\
\hline آغازكر & توليدشده & جندشكل & جند شكل & קندشكل (PIC) \\
\hline $\begin{array}{c}\text { Primer } \\
\text { name }\end{array}$ & $\begin{array}{c}\text { Number of } \\
\text { Produced bands }\end{array}$ & $\begin{array}{c}\text { Number of } \\
\text { Polymorphic bands }\end{array}$ & $\begin{array}{c}\text { Percent of } \\
\text { Polymorphic bands }\end{array}$ & $\begin{array}{c}\text { Polymorphic } \\
\text { information content }\end{array}$ \\
\hline ISSR-9 & 16 & 16 & 100.00 & 0.32 \\
\hline ISSR-10 & 6 & 5 & 83.33 & 0.22 \\
\hline ISSR-4 & 15 & 8 & 53.33 & 0.21 \\
\hline ISSR-1 & 6 & 4 & 66.66 & 0.31 \\
\hline ISSR-2 & 13 & 11 & 84.61 & 0.29 \\
\hline ISSR-14 & 3 & 3 & 100.00 & 0.35 \\
\hline ISSR-20 & 14 & 9 & 64.28 & 0.27 \\
\hline ISSR-5 & 8 & 8 & 100.00 & 0.35 \\
\hline ISSR-7 & 6 & 6 & 100.00 & 0.38 \\
\hline ISSR-3 & 12 & 8 & 66.66 & 0.31 \\
\hline كل (Total) & 99 & 78 & - & - \\
\hline متوسط (Means) & 9.9 & 7.8 & 81.88 & 0.3 \\
\hline
\end{tabular}

Table 6. ISSR primers and results of their amplification

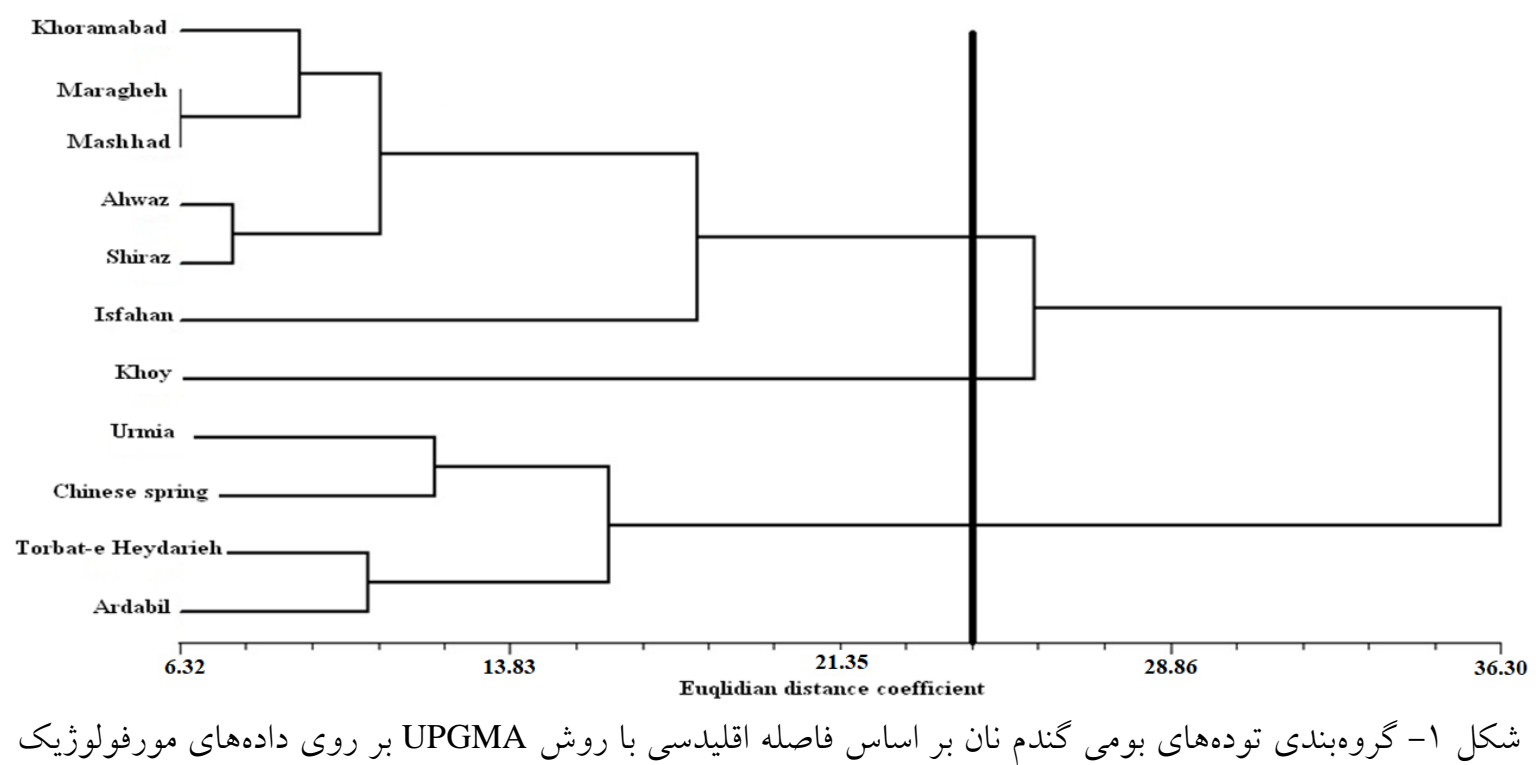

Figure 1. Clustering of Iranian wheat landraces based on Euclidean distance with UPGMA method for morphologic data 
نواربندى براى آغازگر آىاساسآر V نشان داد كه

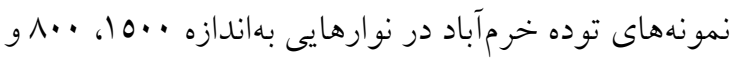
لمفت باز تفاوت داشتند (نتايج نشان داده نشدهاند).

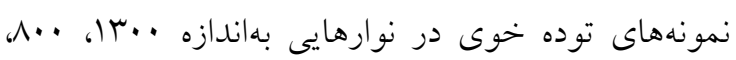

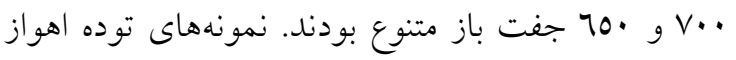

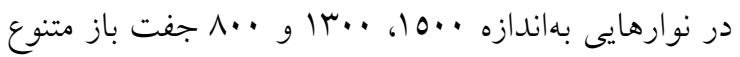

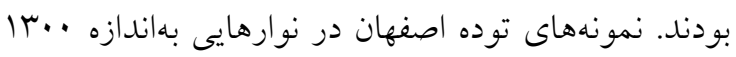

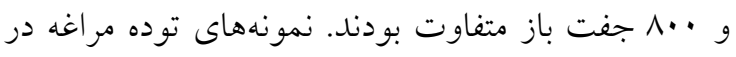

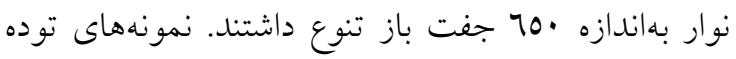

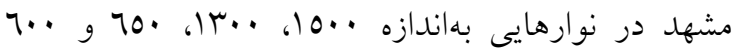

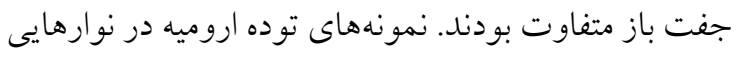
بهاندازه •70 و .77 جفت باز تفاوت داشتند. نمونههاى توده تربتحيدريه در نوار بهاندازه ..با جفت باز متفاوت

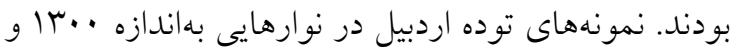

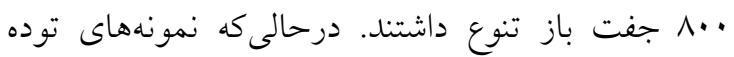
شيراز در همه نوارها الكوى باندى كاملاً مشابهى را داشتند

(نتايج نشان داده نشدهاند).

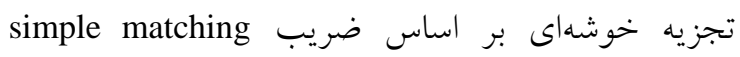

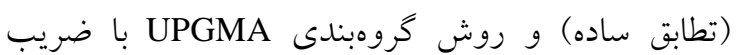

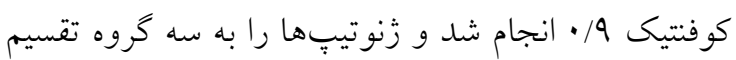

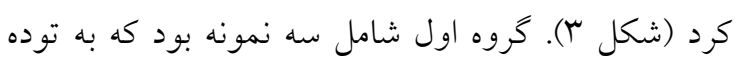

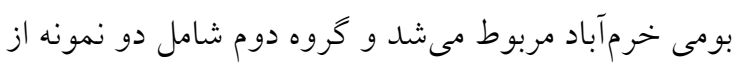

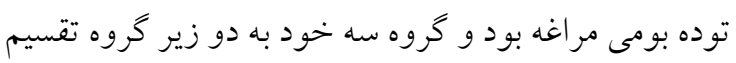
مىشد كه نمونههاى ساير تودهها در اين گروه قرار كرفتند.

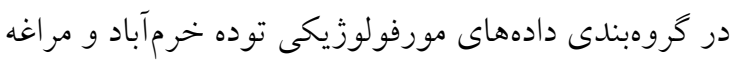

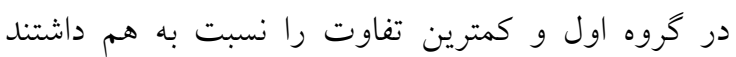

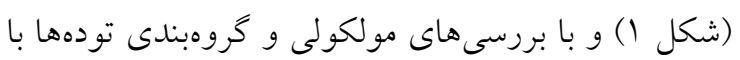

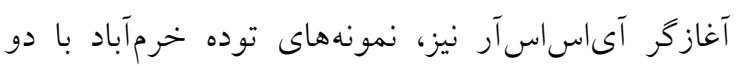

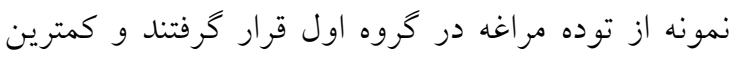
فاصله زنتيكى و بيشترين تشابه را نسبت به داشتند (شكل

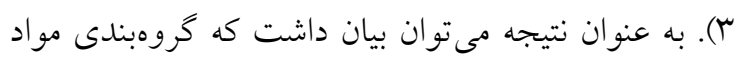
زنتيكى با دادهاى نشانكر مولكولى ISSR با نشانكر

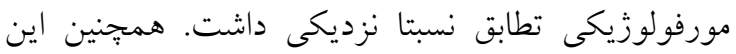
نتايج راهنماى مناسبى جهت انتخاب والدين براى انجام

\section{تعيين الكوى تنوع زُنتيكى تودههاى بومى گندم ايران بر مبناى ...}

شد و براى آغازكرهاى بكار رفته از آ/ • براى آغازگر ع

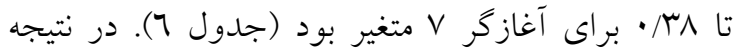

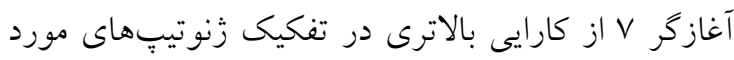

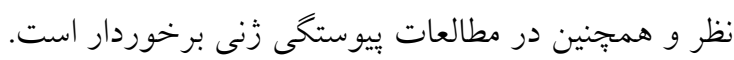

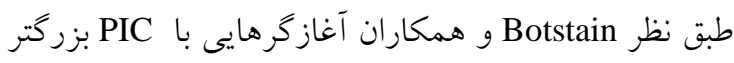

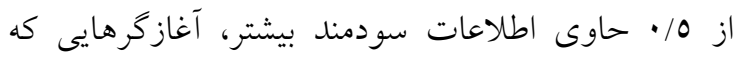

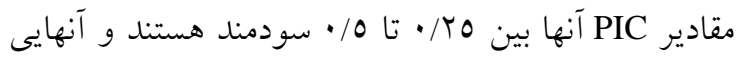

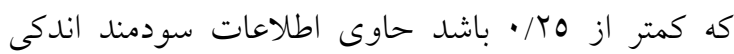
هستند (Botstain et al., 1980). در اين مطالعه ميانخين اين شاخص براى كل تودهها r/٪ بود و با توجه به اينكه

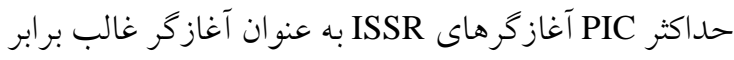
با 10/ خواهد بود مى توان نتيجه كرفت كه اين آغازگرها

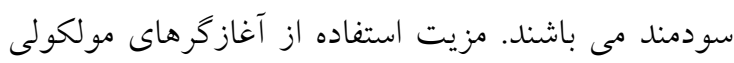

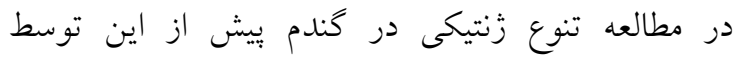
Darvishian

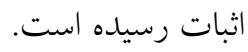
همانطور كه در شكل ؟ براى آغازكر آىاساسآر شماره

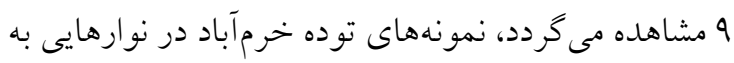

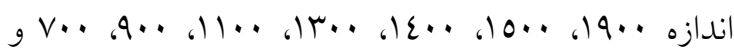

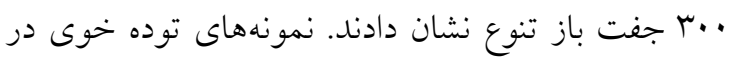

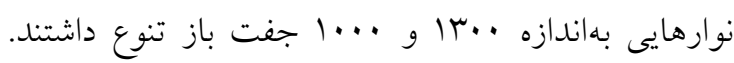

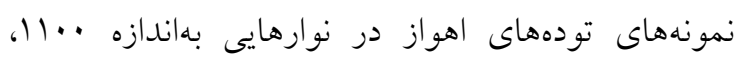

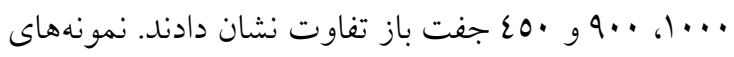

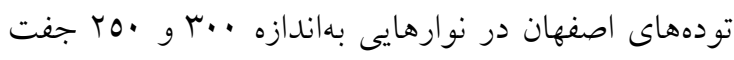

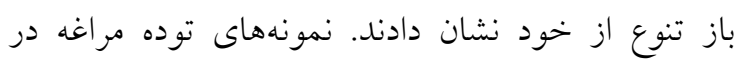

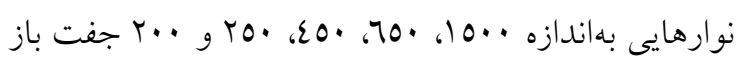
تفاوت نشان دادند. نمونههاى توده مشهد در نوارهايى بـاني بهاندازه ..11، ...1، .70، •0ع و . .ع جفت باز تفاوت داشتند. نمونههاى توده اروميه در نوارهايى بهاندازه ..7 و م جفت باز متفاوت بودند. نمونههاى توده تربت حيدريه

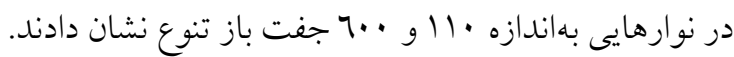
نمونههاى توده شيراز در نوارهايى بهاندازه ...11 و ... جفت باز متفاوت بودند. درحالى كه نمونههاى توده اردبيل در همه نوارها الكوى باندى كاملاً مشابهى را داشتند. نتايج نوليج 
نشانخر AFLP و صفات زراعى نشان دادند كه تنوع زنتيكى

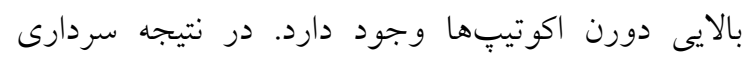

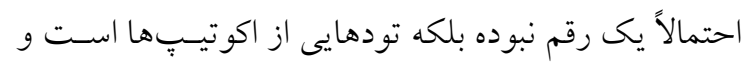

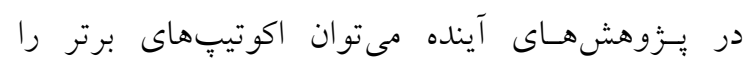

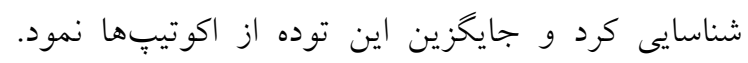

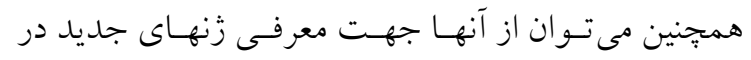

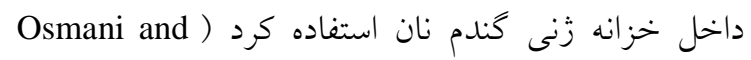

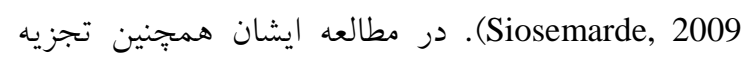

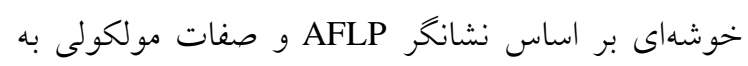

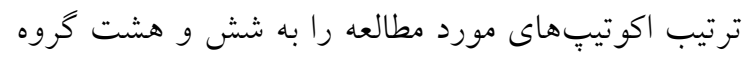

$$
\text { تقسيم كرد. }
$$

نمونهاى توده بومى خرم آباد با آغازگر آىاساسآر 9 در

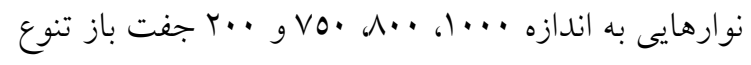

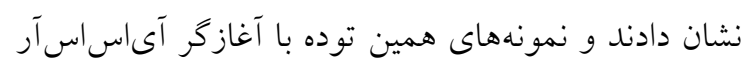

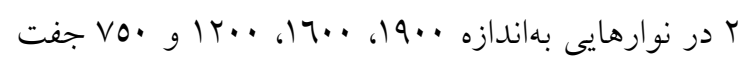

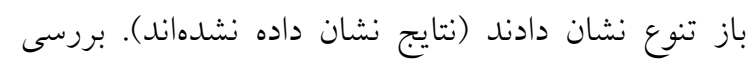

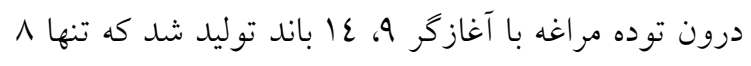

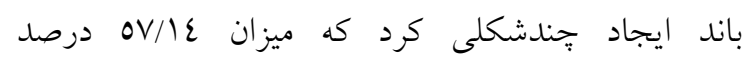

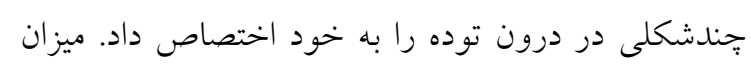

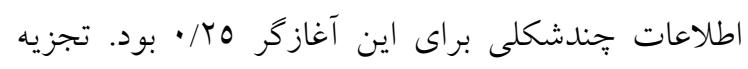

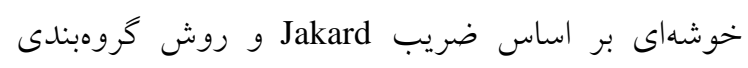
با ضا Single

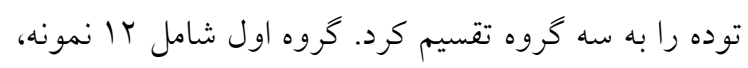

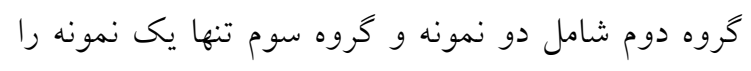

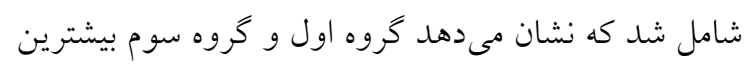

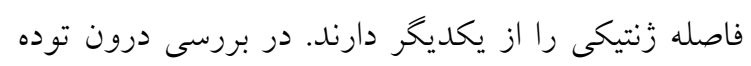

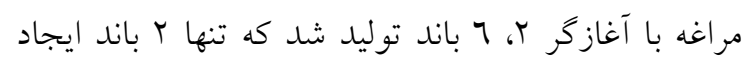

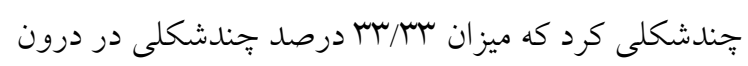

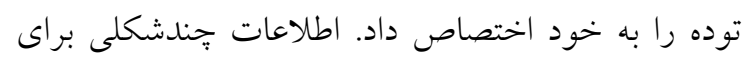

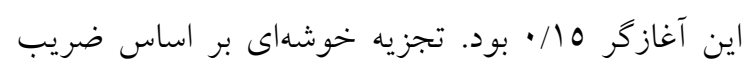

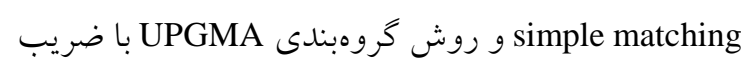
كوفنتيك 9/ • انجام شد و نمونههاى اين توده را به دو كروه رون

$$
\text { تقسيم كرد. }
$$

تلاقى يا توليد ارقام هيبريد خواهد بود. بر اين اساس براى

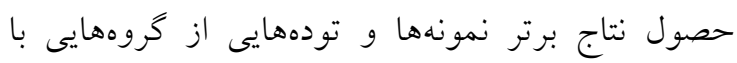

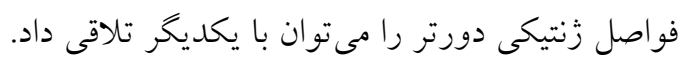

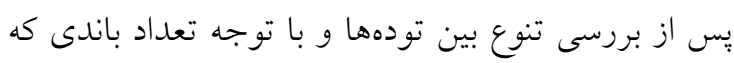

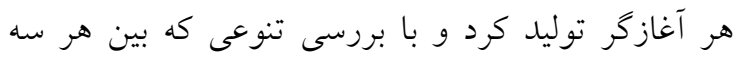

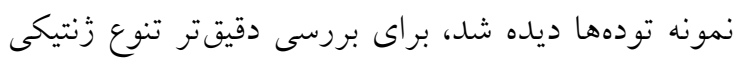

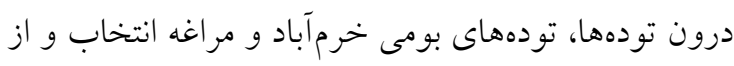

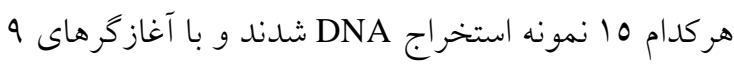

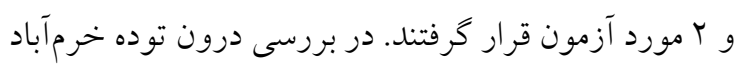

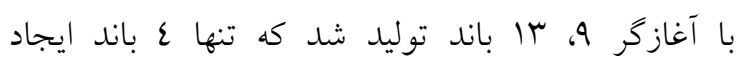

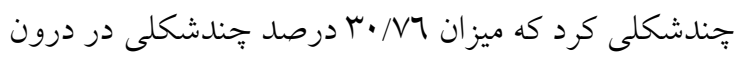
توده را به خود اختصاص داد (نتايج نشان داده نشدهاند).

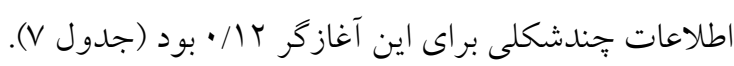
تجزيه خوشهاى بر اساس ضريب simple matching و براى

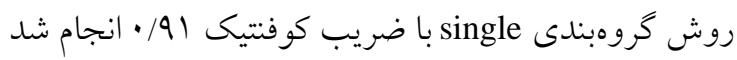
و نمونههاى اين توده را به دو گروه تقسيم كرد. گروه اول

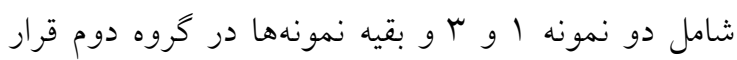

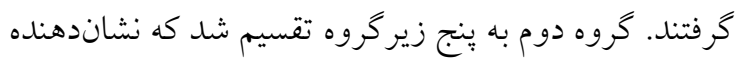

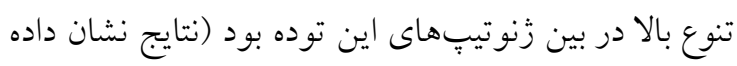

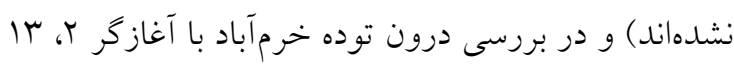

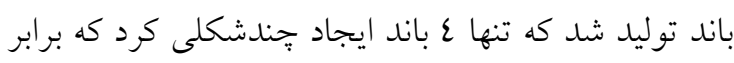

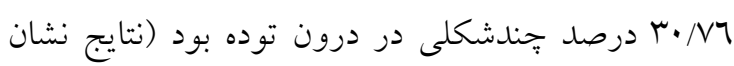
simple داده نشدهاند). تجزيه خوشهاى بر اساس ضرولئ matching

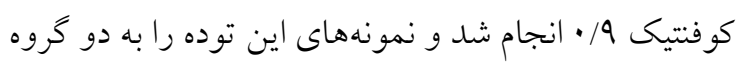

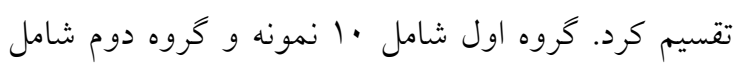

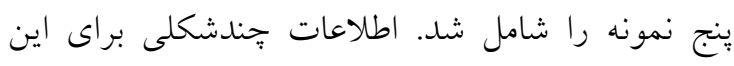

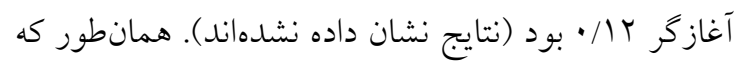

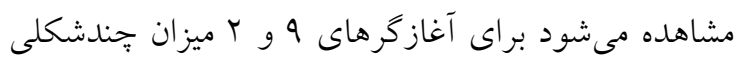
در توده خرمآباد يكسان بود و براى اين توده يك سطح برائ كارايى داشتند. در تحقيقى Osmani و Siosemarde در بررسى تنوع زنتيكى درون اكوتيِهاى گُندم سردارى با استفاده از 


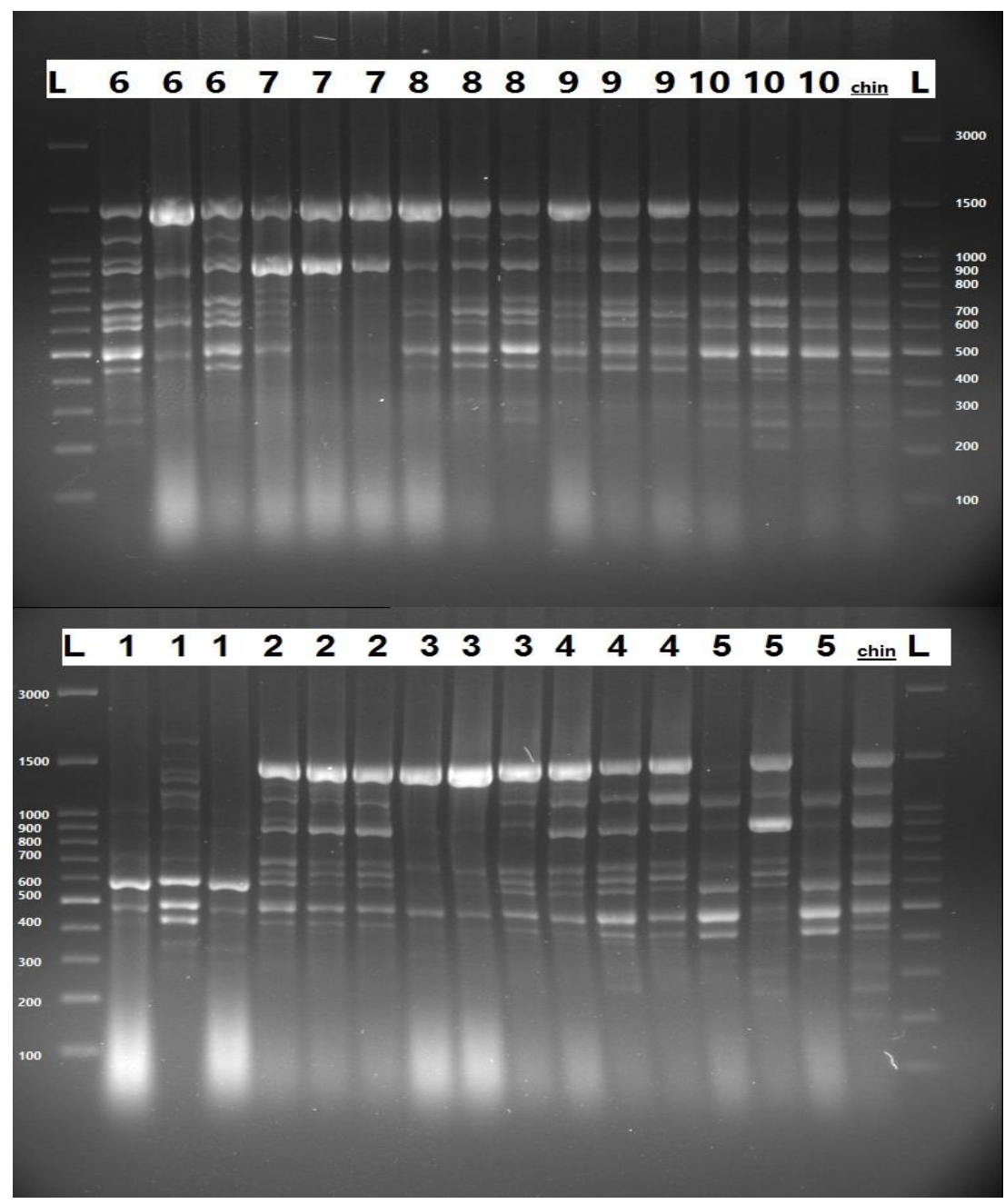

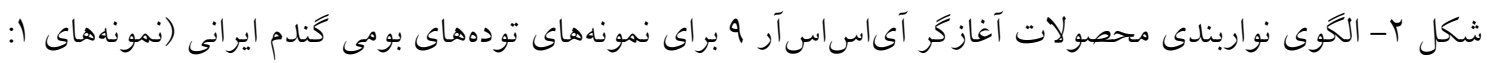

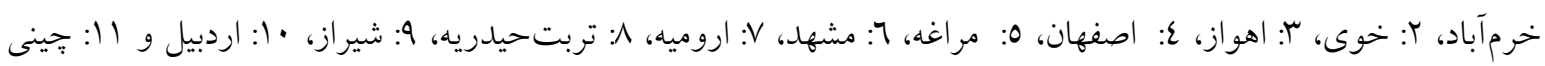
(ب)

Figure 2. Banding pattern of PCR products of ISSR- 9 primer for samples of Iranian wheat landraces (samples 1: Khoramabad; 2: Khoy; 3:Ahwaz; 4: Isfahan; 5: Maragheh; 6: Mashhad; 7:Urmia; 8: Torbat-e Heydarieh; 9: Shraz; 10: Ardabil and 11: Chinese spring)

وضعيت كلى تنوع درون تودههاى بومى گندم مورد بررسى

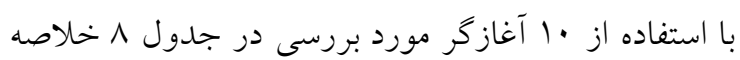

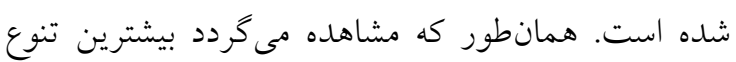

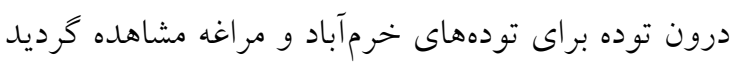

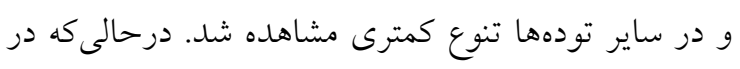

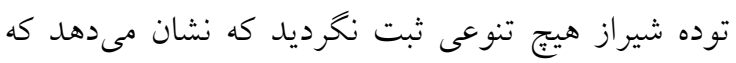

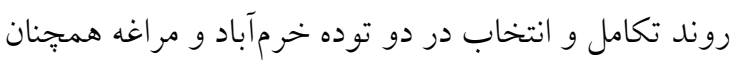
در حال انجام است و از نظر سطح تثبيت زنى ساير تودهها در مر احل بيشرفتهترى قرار دارند.
گروه اول شامل r ا نمونه، گروه دوم سه نمونه را شامل شد

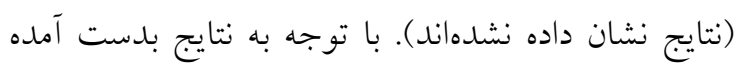

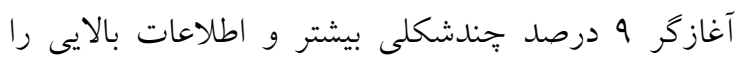

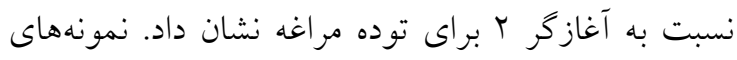

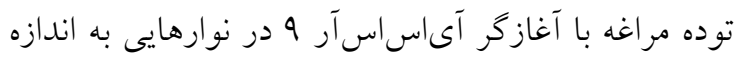

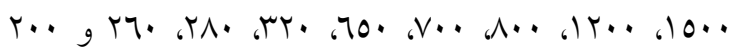
جفتباز تنوع نشان دادند. نمونههاى همين توده با آغازگر

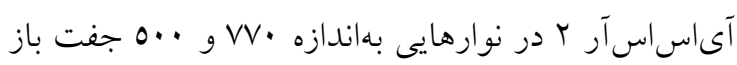
تنوع نشان دادند. 


$$
\text { جدول V- بررسى نمونهاى درون توده خرمآباد با آغازگر } 9
$$

Table 7. Evaluation of samples from Khorramabad landrace with ISSR-9 primer

\begin{tabular}{|c|c|c|c|c|c|}
\hline نام & 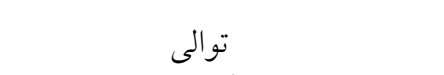 & تعداد باندهاى & تعداد باندهاى & درصد باندهاى جند & محتو اي اطلاعات \\
\hline آغاز گَر & آغاز كر & توليدشده & جندشكل & شكل & جندشكلى (PIC) \\
\hline $\begin{array}{l}\text { Primer } \\
\text { name }\end{array}$ & $\begin{array}{l}\text { Primer } \\
\text { sequence }\end{array}$ & $\begin{array}{l}\text { Number of } \\
\text { Produced bands }\end{array}$ & $\begin{array}{l}\text { Number of } \\
\text { Polymorphic } \\
\text { bands }\end{array}$ & $\begin{array}{l}\text { Percent of } \\
\text { Polymorphic } \\
\text { bands }\end{array}$ & $\begin{array}{l}\text { Polymorphic } \\
\text { information } \\
\text { content }\end{array}$ \\
\hline ISSR-9 & 5-CACACACACACACAGCG-3 & 13 & 4 & 30.76 & 0.12 \\
\hline
\end{tabular}

جدول ^- وضعيت تنوع درون تودههاى بومى گندم ايرانى با استفاده از • ا آغازگر آىاساسآر مورد بررسى Table 8. Intra landrace variation of Iranian wheat by using of ISSR primers

\begin{tabular}{|c|c|c|c|c|c|c|c|c|c|c|}
\hline \multirow[b]{2}{*}{ آغازكر Primer/ } & \multicolumn{10}{|c|}{ ISSR } \\
\hline & 1 & 2 & 3 & 4 & 5 & 7 & 9 & 10 & 14 & 20 \\
\hline Khoramabad & - & * & - & * & * & * & * & * & * & - \\
\hline Khoy & - & - & * & - & - & * & * & - & - & - \\
\hline Ahwaz & * & - & - & - & - & * & * & - & - & - \\
\hline Isfahan & - & - & - & - & - & * & - & * & - & - \\
\hline Maragheh & - & * & * & - & * & - & * & $*$ & - & * \\
\hline Mahhsad & - & * & - & - & - & - & * & $*$ & * & - \\
\hline Urmia & - & - & - & - & - & * & - & - & * & * \\
\hline Torbat-e Heydarieh & - & - & - & - & - & * & * & $*$ & * & - \\
\hline Shiraz & - & - & - & - & - & - & - & - & - & - \\
\hline Ardabil & - & - & - & - & * & * & - & - & * & - \\
\hline
\end{tabular}

$$
\text { * و - : بهترتيب به معنى وجود و عدم وجود تنوع زنتيكى است }
$$

* and -: Genetic variation and no genetic variation, respectively

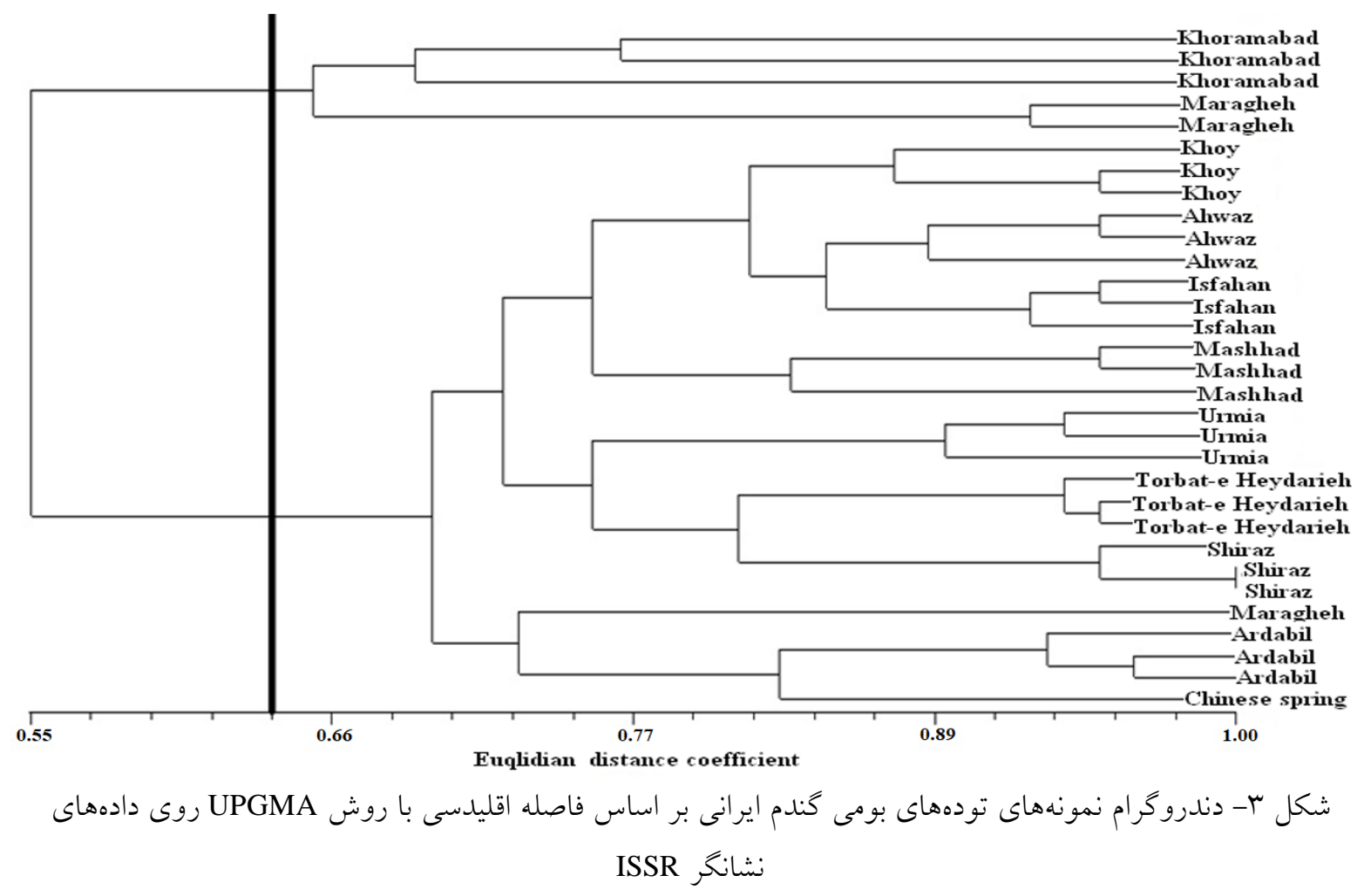

Figure 3. Clustering of Iranian wheat landraces based on Euclidean distance with UPGMA method for ISSR markers data 
مديريت حفظ و نخهدارى منابع زنتيكى در بانكهاى زن

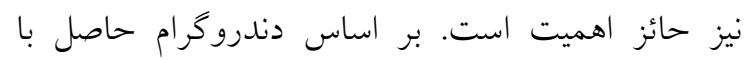

استفاده از روش UPGMA با استفاده از ضريب تشابه ساده

نمونهها به دو كروه تقسيم شدند كه نمونههاى خرمآباد و

مراغه در گروه اول و نمونههاى خوى، اهواز، اصفهان،

مشهد، اروميه، تربتحيدريه، شيراز و اردبيل در گروه دوم

قرار گرفتند. بررسى ميزان قرابت با تجزيه خوشهاى نشان

داد كه نمونههاى توده خرمآباد با نمونههاى توده مراغه

كمترين و توده خرمآباد با توده اردبيل بيشترين فاصله

زنتيكى را داشتند. در كل بر اساس نتايج اين تحقيق مىتوان

ادعا نمود كه تودههاى بومى گندم ايرانى همجنان منبع زنى

مناسبى براى استفاده در برنامههاى اصلاح اين كونه

$$
\text { محسوب مى شوند. }
$$

$$
\begin{aligned}
& \text { درى و آكاهى از تنوع و شباهت زنتيكى در درون تودهها }
\end{aligned}
$$

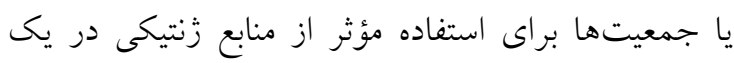

$$
\begin{aligned}
& \text { برنامه اصلاحى ضرورى است. در مجموع، نتايج حاصل از } \\
& \text { اين تحقيق نشان داد كه نشانگر ISSR بهخوبى توانست } \\
& \text { تنوع زنتيكى بين و درون تودههاى بومى گندمها را آشكار } \\
& \text { نمايد. در ضمن نتايج نشان دادند كه سطح تنوع زنتيكى بين } \\
& \text { تودههاى بومى گُندم ايرانى متفاوت است بهطوريكه } \\
& \text { بيشترين تنوع درون توده خرمآباد و كمترين آن در توده } \\
& \text { شيراز مشاهده شد. در كل تنوع درون تودهاى قابل توجهى } \\
& \text { براى تودههاى بومى گندم خرمآباد، مراغه و تربتحيدريه } \\
& \text { از نظر نشانكرهاى آىاساسآر وجود داشت درحالى كه } \\
& \text { براى تودههاى خوى، اهواز، اصفهان، مشهل، اروميه، شيراز } \\
& \text { و اردبيل تنوعى ناجيزى مشاهده شد. اين يافته علاوه بر } \\
& \text { اثبات يتانسيل زنتيكى موجود در اين جمعيتها در امور }
\end{aligned}
$$

\section{References}

Abou-Deif, M.H., Rashed, M.A., Sallam, M.A.A., Mostafa, E.A.H. and Ramadan, W.A. (2013). Characterization of twenty wheat varieties by ISSR markers. Middle-East Journal of Scientific Research, 15(2): 168-175.

Botstain, D., White, R., Skolnick, M. and Davis, R. (1980). Construction of a genetic linkage map in man using restriction fragment length polymorphisms. The American Journal of Human Genetics, 32: $314-331$.

Carvalho, A., Lima-Bito, J., Macas, B. and Guedes-Pinto, H. (2010). Genetic variability analysis of a collection of old Portuguese bread wheat using ISSRs. Options Méditerranéennes, 81: 35-38.

Darvishian, A., Ismaili, A., Nazarian-Firouzabadi, F. and Mirdrikvand, R. (2016). Assessment of genetic diversity among wheat genotypes of west Iran, using randomized markers. Plant Genetic Researches, 2(2): 47-56 (In Persian).

Doyle, J.J., and Doyle, J.L. (1987). A rapid DNA isolation procedure for small quantities of fresh leaf tissue. Phytochemical Bulletin, 19: 11-15.

Evenson, R.E. and Gollin, D. (2003). Assessing the impact of the green revolution. Science, 300: 758762.

Gulnar, S., Ellada, A., Rau, Q., Roham, E., Samira, S. and Javid, O. (2015). Molecular diversity and genetic structure of durum wheat landraces. Albanian Journal of Agricultural Sciences, 14(2): $112-120$

Nazari, M. and Abdolshahi, R. (2014). Evaluation of genetic diversity in bread wheat cultivars (Triticum aestivum L.) using morpho-physiological traits and SSR markers. Journal of Agricultural Biotechnology, 6(1): 215-231(In Persian).

Nikooseresht, R. and Najafian, G. (2016). Genetic Diversity and Heritability for the Selection in Bread Wheat Lines in Kermanshah. Plant Genetic Researches, 3(1): 75-88 (In Persian).

Osmani, J. and Siosemarde, A. (2009). Evaluation of genetic diversity in Sardary wheat ecotypes by AFLP molecular markers. Modern Genetics Journal, 4: 39-48.

Saada, I. and Laward, S. (2015). Molecular characterization of some Syrian bread wheat cultivars. International Journal of ChemTech Research, 8(7): 133-139.

Sofalian, O., Chaparzadeh, N., Javanmard, A. and Hejazi, M.S. (2008). Study the genetic diversity of wheat landraces from northwest of Iran based on ISSR molecular markers. International Journal of Agriculture and Biology, 10: 466-468 (In Persian). 


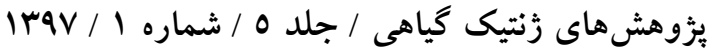

Yanfang, Z., Jin, H., Rui, H., Yang, W. and Shuijin, Z. (2011). Fingerprinting and identification of closely related wheat (Triticum aestivum L.) cultivars using ISSR and fluorescence- labeled TP-M13SSR markers. Australian Journal of Crop Science, 5(7): 846-850.

Zamanianfard, Z., Etminan, A., Mohammadi, R. and Shooshtari, L. (2015). Evaluation of Molecular Diversity of durum wheat genotypes using ISSR markers. In Biological Forum, 7(1): 214218.

Zhou, Y., Zhou, C., Yao, H., Liu, Y. and Tu, R. (2008). Application of ISSR markers in detection of genetic variation among Chinese yam (Dioscorea opposita Thunb) cultivars. Life Science Journal, 5(4): 6-12. 


\title{
Genetic Variation Pattern of Iranian Wheat Landraces Based on ISSR Molecular Markers and Morphological Traits
}

\author{
Arash Salami', Mohammadhadi Pahlevani',*, Khalil Zenalinezhad ${ }^{3}$ \\ and Mohsen Esmaeilzadeh Moghaddam ${ }^{4}$
}

1- Former M.Sc. Student, Department of Plant Breeding and Biotechnology, Gorgan University of Agricultural Sciences and Natural Resources, Gorgan, Iran

2- Associate Professor, Department of Plant Breeding and Biotechnology, Gorgan University of Agricultural Sciences and Natural Resources, Gorgan, Iran

3- Assistant Professor, Department of Plant Breeding and Biotechnology, Gorgan University of Agricultural Sciences and Natural Resources, Gorgan, Iran

4- Assistant Professor, Seed and Plant Improvement Research Institute, Agricultural Research, Education and Extension Organization (AREEO), Karaj, Iran

(Received: October 3, 2017 - Accepted: February 21, 2018)

\begin{abstract}
Collection and conservation of germplasm, particularly for landraces of important agronomically species and organizing their information, cause to continuity of their usefulness and reduce the risk of their genetic erosion. In this experiment, 10 Iranian wheat landraces along with the Chinese Spring cultivar, as control, were used to assess inter and intra populations variation by using ISSR molecular markers and morphological traits. Evaluation of populations in terms of height, spike length, awn length, number of spike nodes, number of grains per spike, flag leaf length and grain weight showed that there were considerable variation among landraces. Also, in some landraces like KhorramAbad and Ardabil, intra population diversity for some of these traits, such as plant height and length of awn, was obvious. Evaluation of the landraces for ISSR markers showed that among 99 scored bands, 78 bands were polymorphic. Percent of polymorphism with mean of $81.88 \%$ was varied from 53.33 for primer of ISSR-4 to $100 \%$ for primers of ISSR-9, ISSR-14, ISSR-5 and ISSR-7. Average PIC of the landraces was estimated 3.0. Results of this study showed that there was considerable intra population diversity for the ISSR markers in landraces of KhorramAbad, Maragheh and Torbat-e-Heydarieh however, a little diversity for Khoy, Ahwaz, Isfahan, Mashad, Urmia, Shiraz and Ardabil was observed. Results of this study showed that there is inter and intra genetic diversity within Iranian landraces of wheat with different levels and these landraces can be used as basic population for extraction of pure lines.
\end{abstract}

Keywords: ISSR, Genetic Diversity, Germplasm, Clustering

\footnotetext{
* Corresponding Author, E-mail: hpahlavani@ gau.ac.ir
} 